\title{
PERLINDUNGAN HUKUM ANAK TERLANTAR ATAS HAK ANAK MENDAPATKAN JAMINAN KESEHATAN
}

\author{
Khoirunnisa, Edith Ratna, Irawati \\ Program Studi Magister Kenotariatan \\ Fakultas Hukum Universitas Diponegoro \\ Email: Khoirunnisa1488@gmail.com
}

\begin{abstract}
Street children is a child who spends most of his time to make money or wandering in the streets or other public places. Article 28 B of the 1945 Law states that the state guarantees every child to live, grow and develop and is entitled to protection from violence and discrimination. Children also have the right to obtain proper health services according to their physical and mental spiritual needs. This research uses a juridical-empirical legal approach (socio-legal research). Adequate child health services are guaranteed in article 8 of the Child Protection Act and Article 62 of Law number 39 of 1999 concerning Human Rights, both for children who have families and abandoned children without families. This study discusses how abandoned children who do not have an identity self and it is unknown who the family can get legal guarantees in terms of health insurance because in Article 34 paragraph (1) of the 1945 Law that the poor and neglected children are looked after by the state.
\end{abstract}

Keyword : street children; protection ; health

\begin{abstract}
Abstrak
Anak jalanan adalah anak yang menghabiskan sebagian besar waktunya untuk mencari nafkah atau berkeliaran di jalanan atau tempat umum lainnya. Pasal 28 B Undang-undang 1945 disebutkan bahwa negara menjamin setiap anak untuk hidup, tumbuh dan berkembang serta berhak atas perlindungan dari kekerasan dan diskiminasi. Anak juga berhak memperoleh pelayanan kesehatan secara layak sesuai dengan kebutuhan fisik dan mental spiritualnya. Artikelini menggunakan pendekatan hukum yuridis-empiris (sosio-legal research).Pelayanan kesehatan anak secara layak dijamin dalam pasal 8 Undang - undang Perlindungan anak maupun Pasal 62 Undang-undang nomor 39 Tahun 1999 tentang Hak Asasi Manusia, baik bagi anak yang memiliki keluarga maupun anak terlantar tanpa keluarga Artikelini membahas bagaimana anak terlantar yang tidak memiliki identitas diri dan tidak diketahui siapa keluarganta dapat memperoleh jaminan hukum dalam hal jaminan kesehatan karena dalam Pasal 34 ayat (1) Undang-undang 1945 bahwa fakir miskin dan anak-anak terlantar dipelihara oleh negara.
\end{abstract}

\section{Kata kunci : anak jalanan; perlindungan; kesehatan.}

\section{A. Pendahuluan}

Anak adalah seseorang yang belum berusia 18 (delapan belas) tahun, termasuk anak yang masih dalam kandungan. Pasal 2 (Kitab Undang -Undang Hukum Perdata)atau Burgerlijk Wetbook menyatakan "Anak yang ada dalam kandungan seorang perempuan, dianggap sebagai telah lahir, setiap kali kepentingan anak menghendakinya. Bila telah mati sewaktu dilahirkan, dia dianggap tidak pernah ada" dapat disimpulkan bahwa anak adalah subjek hukum yang hak- 
haknya harus terpenuhui sejak dalam kandungan hingga terlahir ke dunia, tetapi apabila anak tersebut lahir dalam keadaan meninggal maka dianggap tidak pernah ada.

Secara Psikologis, anak jalanan adalah anak - anak yang pada suatu taraf tertentu belum memiliki cukup mental dan emosional yang kuat, Sementara mereka harus bergelut dengan dunia jalanan yang keras dan cenderung berpengaruh negatif bagi perkembangan dan pembentukan kepribadiannya. (Suyanto, 2013).

Perlindungan anak adalah segala kegiatan untuk menjamin dan melindungi anak dan hak - haknya agar dapat hidup, tumbuh, berkembang, dan berpartisipasi secara optimal sesusai dengan harkat dan martabat kemanusiaan, serta mendapat perlindungan dari kekerasan dan diskriminasi. Perlindungan anak merupakan bagian dari masalah penegakan hukum, yang tidak sederhana, bukan saja karena kompleksitas sistem hukum itu sendiri, tetapi juga rumitnya jalinan hubungan antara wsistem hukum dan sistem sosial, polotik ekonomi dan politik dan budaya masyarakat. Sebagai suatu proses, penegakan hukum pada hakikatnya merupakan variabel yang mempunyai korelasi yan interdevensi dengan fak tor - faktor yang lain. Demikian juga dalam hal perlindungan anak.(Rahardjo, 2009)Anak sebagai generasi penerus bangsa yang harus kita jaga dan membutuhkan perlindungan oleh lingkungan sekitarnya terutama orang tua. Lingkungan tempat berkembang seorang anak akan sangat menentukan bagaimana karakter anak tersebut terbentuk.

Tidak semua anak beruntung mempunyai keluarga yang utuh dan dibesarkan di lingkungan yang baik bahkan ada dan masih banyak anak - anak yang terlantar disekitar kita. Anak terlantar adalah anak yang tidak terpenuhi kebutuhannya secara wajar, baik fisik, mental, spiritual maupun sosial.(Undang - Undang Nomor 17 Tahun 2016 tentang Penetapan Peraturan Pemerintah Pengganti Undang - Undang Nomor 1 Tahun 2016 tentang Perubahan Kedua Atas Undang - Undang Nomor 23 Tahun 2002 tentang Perlindungan Anak Menjadi Undang Undang)yang dimaksud dengan anak terlantar adalah anak yang tidak terpenuhi kebutuhannya secara wajar baik fisik, mental, spiritual, maupun sosial.Istilah-istilah tersebut secara tidak langsung menggambarkan posisi anak jalanan dalammasyarakat. Meskipun memiliki hak penghidupanyang layak seperti anak-anak pada umumnya,tetapi realitanya berbeda dan hampir semua anakjalanan mengalami marginalisasi pada aspek-aspekkehidupannya.(Astri, 2014)

Akibat pengaruh lingkungan sosial, dalam hal ini pengaruh teman sebaya terhadap kecenderungan anak turun ke jalan, adalah dimana seorang anak kemudian mulai mempelajari keahlian - keahlian tertentu dari teman sebayanya dan merasakan bagaimana kehidupan dijalanan sebenarnya. Remaja yang turut mempelajari secara aktif kepentingan - kepentingan 
dan perspektif teman sebaya dalam rangka memuluskan integrasi dirinya dalam aktivitas teman sebaya yang berkelanjutan.(Desmita, 2009)

Negara menjunjung tinggi hak asasi manusia, termasuk di dalamnya hak asasi anak yang ditandai dengan adanya jaminan perlindungan dan pemenuhan hak anak dalam Undang - undang 1945 dan beberapa ketentuan peraturan perundang-undangan baik yang bersifat nasional maupun yang bersifat internasional. Jaminan ini dikuatkan melalui ratifikasi konvensi internasional tentang Hak Anak, yaitu pengesahan Konvensi Hak Anak melalui Keputusan Presiden Nomor 36 Tahun 1990 tentang Pengesahan Convention On The Rights Of The Child (Konvensi Tentang Hak - hak anak).

Pasal 28 B Undang - undang 1945 disebutkan bahwa negara menjamin setiap anak untuk hidup, tumbuh dan berkembang serta berhak atas perlindungan dari kekerasan dan diskiminasi. Pasal ini mempunyai korelasi dengan pasal $28 \mathrm{G}$ yang menyatakan bahwa setiap orang berhak atas perlindungan diri pribadi, keluarga, kehormatan, martabat, dan harta benda yang dibawah kekuasaan, serta berhak atas rasa aman dan perlindungan dari ancaman ketakutan untuk berbuat sesuatu yang merupakan hak asasi. Bertentangan dengan fakta yang ada, anak - anak terlantar yang tidak memiliki keluarga justru tidak mendapat haknya seperti jaminan kesehatan.

Jaminan kesehatan adalah hak semua anak, dimana setiap anak berhak untuk dapat hidup, tumbuh dan berkembang secara optimal. Anak juga berhak memperoleh pelayanan kesehatan secara layak sesuai dengan kebutuhan fisik dan mental spiritualnya. Hal ini dijamin dalam pasal 8 Undang - undang Perlindungan anak maupun Pasal 62 Undang - undang nomor 39 Tahun 1999 tentang Hak Asasi Manusia, baik bagi anak yang memiliki keluarga maupun anak terlantar tanpa keluarga, semua anak memiliki hak yang sama dan tidak dapat dirampas oleh siapa saja. Kenyatannya anak terlantar dan fakir miskin tidak memiliki jaminan kesehatan yang layak, termasuk memperoleh pelayanan kesehatan secara layak sesuai dengan kebutuhan fisik dan mental spiritualnya.

Artikel ini membahas bagaimana anak terlantar yang tidak memiliki identitas diri dan tidak diketahui siapa keluarganya dapat memperoleh jaminan hukum dalam hal jaminan kesehatan karena dalam Pasal 34 ayat (1) Undang-Undang 1945 bahwa fakir miskin dan anak anak terlantar dipelihara oleh negara.

Penulis menemukan adanya kemiripan dengan artikel lainnya dalam bentuk jurnal, yang dapat menjadi referensi dalam artikel ini. Menghindari adanya plagiatisme dalam artikel ini berikut perbedaan artikel ini dan artikel lainnya yaitu: 
1. Damanhuri Warganegara, "Perlindungan Hukum Terhadap Anak Jalanan", Jurnal Ilmu Hukum, 2017. Jurnal ini membahas masalah - masalah yang terjadi pada anak jalanan dan bagaimana bentuk perlindungan terhadap anak jalanan. (Warganegara, 2017)

2. Herlina Astri, "Kehidupan Anak Jalanan di Indonesia : Faktor penyebab, tatanan hidup dan kerentanan berprilaku menyimpang", 2014. Jurnal ini membahas penyebab munculnya anak jalanan, dan kerentanan anak jalanan terhadap perilaku menyimpang.(Astri, 2014)

3. Pipin Armita, "Meningkatkan Kesejahteraan Sosial Anak Jalanan dengan Teori Self Esteem", 2016. Jurnal ini membahas pendekatan sosial yang dilakukab oleh komunitas atau lembaga sosial berupa teori self esteem yang dimiliki anak jalanan, untuk memberikan solusi yang mendasar dalam meningkatkan kesejahteraan sosial anak jalanan.(Armita, 2016)

Terdapat beberapa hal yang membedakan artikel ini dan artikel-artikel sebelumnya yaitu artikel ini membahas hak - hak anak yang wajib didapatkan walaupun anak jalanan tidak memiliki keluarga, salah satunya jaminan kesehatan.

\section{B. Metode}

Metode penelitian adalah cara utama yang digunakan oleh para peneliti untuk mencapai tujuan dan menentukan jawaban masalah yang diajukan. Artikel ini menggunakan pendekatan hukum yuridis - empiris (sosio-legal research). Pendekatan yuridis adalah suatu pendekatan yang mengacu pada hukum dan peraturan perundang-undangan yang berlaku, sedangkan pendekatan normative adalah penelitian terhadap data sekunder bidang hokum (Amiruddin, 2004). Data sekunder terdiri dari bahan hukum primer, bahan hukum sekunder, dan bahan hukum tersier, sehingga dalam mengolah dan menganalisis bahan hukum tersebut tidak bisa melepaskan diri dari berbagai penafsiran yang dikenal dalam ilmu hukum. Spesifikasi penelitian yang digunakkan dalam artikel ini adalah deskriptif analitis.Jenis penelitian hukum empiris merupakan jenis artikelyang menganalisa suatu permasalahan hukum atau isu hukum berdasarkan suatu permasalahan yang ada dalam masyarakat itu sendiri dengan cara mendapatkan data lapangan (Burhan, 2001). Bahan hukum yang digunakan dalam penelitian ini adalah bahan hukum primer, bahan hukum skunder dan bahan hukum tersier. Teknik pengumpulan data yang digunakan adalah studi kepustkaan, yang didukung data lapangan melalui observasi. 


\section{Hasil Dan Pembahasan}

Anak adalah seseorang yang belum berusia 18 (delapan belas) tahun, termasuk anak yang masih dalam kandungan, hal ini tercantum dalam Pasal 1 (Undang - Undang Nomor 23 Tentang Perlindungan Anak). Anak adalah potensi dan generasi muda penerus cita - cita bangsa yang memiliki peran strategis dan mempunyai harapan pembentuk karakter negara di masa depan. Setiap anak kelak akan memikul tanggung jawab yang berbeda - beda, maka semua anak perlu mendapat kesempatan yang seluas - luasnya untuk tumbuh, berkembang, dan mengekspresikan semua potensi atau bakat yang mereka miliki. Anak - anak juga mepunyai hak untuk berkembang secara optimal baik fisik, mental maupun sosial. Undang - undang Nomor 23 Tahun 2002 tentang Perlindungan Anak.

Menurut Kementerian Sosial RI, anak jalanan adalah anak yang menghabiskan sebagian besar waktunya untuk mencari nafkah atau berkeliaran di jalanan atau tempat umum lainnya. Anak jalanan dalam konteks ini adalah anak yang berusia antara enam sampai dengan delapan belas tahun. Sosok anak jalanan bermunculan dikota-kota, baik itu di emper-emper toko, di stasiun, terminal, pasar, tempat wisata bahkan ada yang dimakam-makam, anak-anak jalanan menjadikan tempat mangkalnya sebagai tempat berteduh, berlindung, sekaligus mencari sumber kehidupan, meskipun ada juga yang masih tinggal dengan keluarganya. Jumlah anak jalanan dari tahun ke tahun selalu mengalami peningkatan (Armita, 2016).

Fenomena anak jalanan berhubungan dengan masalah-masalah lain, baik secara internal maupun eksternal, seperti ekonomi, psikologi, sosial, budaya, lingkungan, pendidikan, agama, dan keluarga. Mereka korban dari kondisi yang dialami individu, baik internal, eksternal maupun kombinasi keduanya. Munculnya anak jalanan, tidak bisa dilihat dari faktor ekonomi saja, tetapi banyak faktor yang menjadi pemicu, seperti kemiskinan, perhatian keluarga, kenakalan remaja, pola asuh yang salah.

Munculnya fenomena anak jalanan, yaitu sejumlah kebijakan makro dalam bidang sosial ekonomi telah menyumbang munculnya fenomena anak jalanan. Modernisasi, industrialisasi, migrasi dan urbanisasi menyebabkan terjadinya perubahan jumlah anggota keluarga dan gaya hidup yang membuat dukungan sosial dan perlindungan terhadap anak menjadi berkurang. Kekerasan dalam keluarga menjadi latar belakang penting yang menyebabkan anak keluar dari rumah yang mengalami tekanan ekonomi dan jumlah anggota keluarga yang besar. Terkait permasalahan ekonomi, sehingga anak terpaksa ikut membantu orang tua dengan bekerja di 
jalanan. Orang tua "mengaryakan" sebagai sumber ekonomi keluarga pengganti peran yang seharusnya dilakukan oleh orang dewasa.

Tidak tuntasnya penanganan anak jalanan selama ini disebabkan karena beberapa hal yaitu program penanganan anak jalanan yang selama ini dilakukan cenderung hanya bersifat parsial, tidak tepatsasaran, kurang sinergisnya penyelenggara penanganan anak jalanan baik di internal pemerintah maupun antara pemerintah dengan stakeholder lainnya (rumah singgah,swasta, Lembaga Swadaya Masyarakat), tidak adanya keberlanjutan dari program program yang dilakukan dan sebagainya. Kondisi inilah yang menyebabkan program program penanganan anak jalanan yang dilakukan tidak pernah mampu menyentuh akar persoalan.(Suyatna, 2011)

Perlindungan anak merupakan upaya penting dan segera harus dilakukan, karena perlindungan anak merupakan usaha membangun investasi terbesar peradaban suatu bangsa, sebab apabila fenomena berbagai bentuk kekerasan terus menimpa kaum anak, bukan tidak mungkin ketika mereka mencapai usia dewasa, akan menjadi penyumbang terbesar kejahatan disebuah negara, demikian juga sebaliknya jika sedari muda mereka mendapat kasih sayang dan perlakuan yang benar, maka paling tidak cengkraman patologis dan psisko-sosial tidak begitu kuat mempengaruhi mereka untuk berbuat jahat.

Perlindungan anak sudah semestinya tetap berpedoman pada upaya yang holistik yang menjadikan anak sebagai manusia yang patut mendapat perhatian yang baik. Dalam konteks ini Abdul Hakim Garuda Nusantara, mantan Ketua Komnas HAM RI mengatakan, bahwa masalahnya tidak semata-mata bisa didekati secara yuridis, tetapi perlu pendeatan yang lebih luas yaitu, ekonomi, sosial dan budaya. Sejalan dengan itu Shanti Dellyana mengatakan, bahwa perlindungan merupakan satu usaha yang mengadakan kondisi di mana setiap anak dapat melaksanakan hak dan kewajibannya(Nasution, 2006).

Perlindungan anak merupakan bagian dari masalah penegakan hukum yang tidak sederhana, karena rumitnya jalinan hubungan antara sistem hukum dengan sistem sosial, politik, ekonomi dan budaya masyarakat. Sebagai suatu proses, penegakan hukum pada hakikatnya merupakan variabel yang mempunyai hubungan dan interdevendensi dengan faktor - faktor yang lain, demikian juga dlam hal perlindugan anak.

Permasalahan anak harus diatasi secara kompleks. Proses untuk mengantisipasi perkembangan fisik, jiwa dan mental maupun kehidupan sosiologis yang lebih baik. (Undang Undang Nomor 4 Tahun 1979 tentang kesejahteraan anak) mengatur mengenai hak - hak anak yang terdapat dalam Pasal 2. 
Pasal tersebut menjelaskan adanya perlindungan anak dalam rangka mengusahakan kesejahteraan anak dan perlakuan yang adil terhadap mereka. Hal ini penting demi kelangsungan kegiatan perlindungan anak dan mencegah penyelewengan yang membawa akibat negatif yang tidak diharapkan dalam upaya perlindungan anak. Adanya suatu rasa tanggung jawab dalam pelaksanaan perlindungan anak dan juga rasa keadilan yang dapat mempengaruhi kelangsungan kegiatan dalam upaya pelaksanaan perlindungan anak tersebut. Tanggung jawab dalam pelaksanaan perlindungan anak dan juga rasa keadilan yang dapat mempengaruhi kelangsungan kegiatan dalam upaya pelaksanaan perlindungan anak tersebut.

Pasal 3 Undang-Undang Nomor 23 Tahun 2002 dinyatakan bahwa perlindungan anak bertujuan untuk menjamin terpenuhinya hak-hak anak agar dapat hidup, tumbuh, berkembang, dan berpartisipasi secara optimal sesuai dengan harkat dan martabat kemanusiaan, serta mendapat perlindungan dari kekerasan dan diskriminasi, demi terwujudnya anak Indonesia yang berkualitas, berakhlak mulia, dan sejahtera. Namun dalam hal ini fakta menunjukkan lain terhadap kehidupan anak, terutama anak jalanan. Fenomena anak jalanan di Indonesia adalah masalah sosial yang kompleks. Hidup menjadi anak jalanan sesunggunya bukanlah merupakan pilihan yang menyenangkan, karena mereka berada pada kondisi yang tidak memiliki masa depan yang jelas. Keberadaan anak jalanan sering dianggap sebagai biang persoalan oleh berbagai pihak, mulai dari keluarga, masyarakat, dan Negara. Namun yang patut disayangkan adalah bahwa selama ini kita belum memberikan pehatian yang besar kepada mereka.

Anak terlantar sendiri pada umumnya merupakan anak - anak yang berasal dari latar belakang keluarga yang berbeda - beda, ada yang berasal dari keluarga tidak mampu sehingga memaksa mereka untuk turun kejalan dan membantu perekonomian keluarga, ada juga yang memang tidak diketahui asal usul orang tua dan keluarganya sehingga hilangnya kasih sayang dan memberatkan jiwa yang berakibat terbentuknya karakter yang negatif.

Penanganan anak jalanan yang dilakukan haruslah mengacu pada pada tiga tujuan utama perlindungan sosial yaitu mencegah dan mengurangi resiko yang dialami manusia sehingga terhindar dari kesengsaraan yang parah dan berkepanjangan meningkatkan kemampuan kelompok - kelompok rentan dalam menghadapi dan keluar dari kemiskinan, kesengsaraan, dan ketidaksamaan sosial ekonomi serta memungkinkan kelompok - kelompok miskin untuk memiliki standar hidup yang bermartabat (Suharto, 2009).

Beberapa masalah yang paling mendasar yang dialami oleh anak terlantar adalah kesehatan dan pendidikan.Program pendidikan dapat digunakan untuk mengajarkan anak mengatasi dan mengelola stress, membangun hubungan sosial positif, bertanggung jawab dan belajar mengurus 
kesehatan fisik dan psokologis.(D. Geldard, 2012) Hal ini sejalan dengan gagasan Tilaar yang mengatakan bahwa pendidikan mempunyai hakikat sebagai pembebasan manusia.(HAR, 2009). Selain itu esehatan anak anak terlantar sangat tidak terjamin karena mereka hidup disembarang tempat yang kadang tidak layak untuk dihuni dan tidak ada yang memperhatikan kesehatan mereka. Setiap anak berhak dapat hidup, tumbuh dan berkembang secara optimal, termasuk didalamnya untuk memperoleh pelayanan kesehatan secara layak sesuai dengan kebutuhan fisik dan mental spiritualnya. Hal ini dijamin dalam Pasal 62 (Undang - Undang Nomor 39 Tahun 1999 Tentang Hak Asasi Manusia), baik bagi anak yang memiliki keluarga maupun anak terlantar tanpa keluarga, semuanya memiliki hak yang sama dan tidak dapat dirampas oleh siapapun.

Pemerintah wajib menyelenggarakan upaya kesehatan yang komprehensif bagi anak. Namun dimata hukum, seorang anak belum cakap melakukan perbuatan hukum seperti untuk membuat persyarataan administrasi yang diperlukan atau mengambil jaminan kesehatan apa yang di butuhkan. Oleh karena itu untuk mengakses manfaat dari penyelenggaraan jaminan kesehatan yang telah disediakan pemerintah, anak perlu berada dalam pengasuhan (Gibson, 2011).

Pasal 1 angka 2 (Peraturan Menteri Sosial Nomor 21 Tahun 2013 tentang Pengasuhan Anak) menjelaskan bahwa pengasuhan anak adalah upaya untuk memenuhi kebutuhan akan kasih sayang, kelekatan, keselamatan, dan kesejahteraan yang menetap dan berkelanjutan demi kepentingan terbaik anak, yang dilaksanakan baik oleh orang tua atau keluarga sampai derajat ketiga maupun orang tua asuh, orang tua angkat, wali serta pengasuhan berbasis residensial sebagai alternatif terakhir. Hal ini juga dijelaskan dalam Pasal 55 ayat (1) Undang -undang 35 tahun 2014 tentang perubahan atas Undang - undang nomor 23 tahun 2002 tentang Perlindungan anak, dimana pemeliharaan, perawatan dan rehabilitasi sosial anak terlantar wajib diselenggarakan oleh pemerintah pusat dan pemerintah daerah, baik dalam lembaga (melalui sistem panti pemerintahan dan panti swasta) maupun di luar lembaga (sistem asuhan keluarga / perseorangan).

Apabila anak didapati di jalanan tanpa memiliki keluarga yang dapat dihubungi atau dituju, petugas yang berwenang akan membawanya ke panti sosial sementara dimana akan dilakukan pendataan dan asesmen terhadap anak. Lalu anak diberi pembinaan baik fisik, spiritual dan sosial selama kurang lebih 1 bulan. Setelah waktu tersebut, anak akan diserahkan kepada Lembaga Kesejahteraan Sosial Anak (LKSA) sampai diperolehnya pengasuhan berbasis keluarga yang permanen (orang tua asuh, wali, atau orang tua angkat).Pasal 57 (Peraturan Pemerintah 
Pengganti Undang - Undang Nomor 1 Tahun 2016 tentang Perlindungan Anak)juga memberikan kemungkinan bagi lembaga yang menyelenggarakan pemeliharaan anak terlantar atau pejabat yang berwenang dapat mengajukan permohonan ke pengadilan untuk menetapkan anak sebagai anak terlantar. Penetapan pengadilan tersebut nantinya sekaligus menetapkan tempat penampungan, pemeliharaan, dan perawatan anak terlantar yang bersangkutan.

\section{Simpulan}

Anak jalanan adalah anak yang menghabiskan sebagian besar waktunya untuk mencari nafkah atau berkeliaran di jalanan atau tempat umum lainnya. Anak jalanan dalam konteks ini adalah anak yang berusia antara enam sampai dengan delapan belas tahun. Fenomena anak jalanan berhubungan dengan masalah-masalah lain, baik secara internal maupun eksternal, seperti ekonomi, psikologi, sosial, budaya, lingkungan, pendidikan, agama, dan keluarga. Tidak tuntasnya penanganan anakjalanan selama ini disebabkan karenabeberapa hal yaitu program penanganananak jalanan yang selama ini dilakukan cenderung hanya bersifat parsial, tidak tepatsasaran, kurang sinergisnya penyelenggarapenanganan anak jalanan baik di internalpemerintah maupun antara pemerintahdengan stakeholder lainnya (rumah singgah,swasta, Lembaga Swadaya Masyarakat)

Beberapa masalah yang paling mendasar yang dialami oleh anak terlantar adalah kesehatan dan pendidikan. Pemerintah wajib menyelenggarakan upaya kesehatan yang komprehensif bagi anak.Pasal 1 angka 2 (Peraturan Menteri Sosial Nomor 21 Tahun 2013 tentang Pengasuhan Anak)menjelaskan bahwa pengasuhan anak adalah upaya untuk memenuhi kebutuhan akan kasih sayang, kelekatan, keselamatan, dan kesejahteraan yang menetap dan berkelanjutan demi kepentingan terbaik anak, yang dilaksanakan baik oleh orang tua atau keluarga sampai derajat ketiga maupun orang tua asuh, orang tua angkat, wali serta pengasuhan berbasis residensial sebagai alternatif terakhirApabila anak didapati di jalanan tanpa memiliki keluarga yang dapat dihubungi atau dituju, petugas yang berwenang akan membawanya ke panti sosial sementara dimana akan dilakukan pendataan dan asesmen terhadap anak. Lalu anak diberi pembinaan baik fisik, spiritual dan sosial selama kurang lebih 1 bulan.

\section{DAFTAR PUSTAKA}

\section{Buku}

Amiruddin, A. (2004). Pengantar Metode ArtikelHukum. Jakarta: PT. Raja Grafindo. 
Armita, P. (2016). Meningkatkan Kesejateraan Sosial Anak Jalanan dengan Teori Self Esteem. PKS, 15 Nomor 4.

Astri, H. (2014). Kehidupan Anak Jalanan Di Indonesia: Faktor Penyebab, Tatanan Hidup Dan Kerentanan Berprilaku Menyimpang. P3DI, 1 .

Burhan, A. (2001). Metode ArtikelHukum. Jakarta: Rineka Cipta.

Desmita, D. (2009). Psikologi Perkembangan Peserta Didik (Panduan bagi Orangtua dan Guru dalam Memahami Psikologi Anak Usia SD, SMP, SMA). Bandung: PT. Remaja Rosdakarya.

Geldard, D. (2012). Konseling Remaja Intervensi Praktis Bagi Remaja Beresiko (K. Geldard, ed.). Yogyakarta: Pustaka Pelajar.

Gibson, R. L. (2011). Bimbingan dan Konseling. Yogyakarta: Pustaka Pelajar.

HAR, T. (2009). Kekuasaan dan Pendidikan Manajemen Pendidikan Nasional Dalam Pusaran Kekuasaan. Jakarta: PT. Rineka Cipta.

Nasution, A. H. G. (2006). Prospek Perlindungan Anak. Jakarta: Rajawali.

Rahardjo, S. (2009). Penegakan Hukum Suatu Tinjauan Sosiologis. Yogyakarta: Genta Publishing.

Suharto, E. (2009). Kemiskinan dan Perlindungan Sosial Di Indonesia. Bandung: Alfabeta.

Suyanto, B. (2013). Masalah Sosial Anak. Jakarta: Kencana Pranada Media Group.

Suyatna, H. (2011). Revitalisasi Model Penanganan Anak Jalanan di rumah Singgah. Ilmu Sosial Dan Ilmu Politik, 15 Nomor 1(Sosial).

Warganegara, D. (2017). Perlindungan Hukum Terhadap Anak Jalanan. Hukum.

\section{Artikel Jurnal}

Armita, P. (2016). Meningkatkan Kesejateraan Sosial Anak Jalanan dengan Teori Self Esteem. PKS, 15 Nomor 4.

Astri, H. (2014). Kehidupan Anak Jalanan Di Indonesia: Faktor Penyebab, Tatanan Hidup Dan Kerentanan Berprilaku Menyimpang. P3DI, 1 .

Suyatna, H. (2011). Revitalisasi Model Penanganan Anak Jalanan di rumah Singgah. Ilmu Sosial Dan Ilmu Politik, 15 Nomor 1(Sosial). 


\section{Undang-undang dan Peraturan}

Undang-undang Dasar Negara Republik Indonesia Tahun 1945.

Undang-undang Nomor 17 Tahun 2016 tentang Penetapan Peraturan Pemerintah Pengganti Undang-undang Nomor 1 Tahun 2016 tentang Perubahan Kedua Atas Undang - Undang Nomor 23 Tahun 2002 tentang Perlindungan Anak Menjadi Undang - Undang.

Undang-undang Nomor 23 Tentang Perlindungan Anak.

Undang-undang Nomor 39 Tahun 1999 Tentang Hak Asasi Manusia.

Undang-undang Nomor 4 Tahun 1979 tentang kesejahteraan anak.

Kitab Undang-undang Hukum Perdata.

Peraturan Pemerintah Pengganti Undang - Undang Nomor 1 Tahun 2016 tentang Perlindungan Anak.

Peraturan Menteri Sosial Nomor 21 Tahun 2013 tentang Pengasuhan Anak. 